\title{
Chaoul Pereyra, María Eugenia (2014), Entre la esperanza de cambio y la continuidad de la vida. El espacio de las escuelas primarias nacionales en la Ciudad de México, 1891-1919, México, Instituto Mora
}

\author{
Verónica Arellano Rosales \\ Centro de Investigación y de Estudios Avanzados \\ varellan@cinvestav.mx
}

En diciembre del 2014 se publicó el libro Entre la esperanza de cambio y la continuidad de la vida. El espacio de las escuelas primarias nacionales en la Ciudad de México, 1891-1919, cuya autora es la doctora en historia María Eugenia Chaoul Pereyra. Profesora investigadora del Instituto Mora, se distingue por su trayectoria académica dedicada al estudio de la dinámica escolar en la Ciudad de México hacia finales del siglo xIX y principios del XX. Este libro nos muestra un estudio minucioso que da cuenta del tránsito, durante el Porfiriato, de la educación primaria en manos del Ayuntamiento al control del Estado, mediante la regulación y promulgación de leyes en lo que se denominó "Federalización de la Enseñanza".

Esta obra expone aquellas ideas, reflexiones y miradas con las que María Eugenia Chaoul se acercó a su tema de estudio. Guiada por las enseñanzas de su maestro y director de tesis de maestría y doctorado, el Dr. Ariel Rodríguez Kuri, recrea la vida cotidiana de las escuelas primarias de la Ciudad de México a finales del siglo XIX y, al mismo tiempo, describe la transformación arquitectónica, cultural y social de la ciudad. El periodo de estudio que elige comprende 29 años, que van de 1891 a 1919, lo que significa un gran acierto, puesto que permite repensar un fenómeno social no por etapas históricas, sino por acontecimientos, de manera que traspasa las fronteras de la "pax" porfiriana para adentrarnos en los días de la revuelta social, económica y política, que más tarde se denominaría Revolución mexicana. Desde su narrativa nos ofrece elementos para mirar, a través de la línea del tiempo, las tácticas y estrategias del Estado para asumir o deslindarse del proyecto educativo nacional.

Entre los aportes de Chaoul destacan la destreza para hacer converger en su análisis la diversidad de fuentes: periódicos, leyes, boletines, anuarios, así como planos de escuelas, informes, fotografías, inventarios y oficios, entre otros, que rescata de los archivos históricos 
consultados. A través de sus hallazgos, muestra los alcances y límites de la instauración del Estado a nivel nacional en el plano educativo. Al mismo tiempo que describe la ley de instrucción pública de 1891 que intentó reglamentar el tiempo escolar, narra el impacto que ésta tuvo en el funcionamiento de las escuelas elementales al requerir un consejo de vigilancia que obligaba a los padres de familia a cumplir con ese deber, ya fuera voluntariamente o mediante coacción.

Por otra parte, Chaoul entrelaza los datos cuantitativos que las estadísticas de la época reportan con aquellos datos cualitativos que obtuvo del diálogo con los informes y memorias pedagógicas de la época, así como con las notas periodísticas de los diversos boletines y revistas analizadas. Un aporte más es la selección de fotografías con que ilustra uno de los temas en los que más profundizó su análisis: la salud e higiene de las escuelas, como símbolo de la transformación de la vida escolar. A través de las imágenes nos conduce en un recorrido por un edificio escolar de una escuela modelo; una exhibición del tratamiento de tiña al que eran sometidos los alumnos y una visita a los primeros comedores escolares que se instauraron en 1911. Las siete fotografías nos Ilevan a imaginar aquellas escuelas, salones y comedores llenos de voces, de silencios, de miradas, aprendizajes, historias y emociones.

El libro está organizado en cuatro capítulos. En el primero explica los intentos por transformar, mediante decretos y leyes, las escuelas municipales en escuelas federales y lo que esto implicó para la organización educativa en el marco del Porfiriato, periodo de aparente estabilidad social, económica y política. Al mismo tiempo que refiere el contexto social y el impacto de la expansión urbana en la Ciudad de México, a finales del siglo xx, plantea el trabajo social y político de los congresos higiénicos y pedagógicos, donde se establecieron las bases que marcarían un ritmo y un tiempo escolar, dándole forma al sistema educativo nacional que se gestaba.

En el segundo capítulo, Chaoul muestra planos e imágenes de los nuevos edificios escolares, que respondían a las cuestiones higiénicas y arquitectónicas emergentes a nivel internacional y constituían los modelos a seguir. A través de los informes emitidos por las autoridades educativas y la descripción de los planos, incursionamos en la cotidianidad escolar, recorremos escuelas de vecindades donde la vida escolar transcurría entre lo público y lo privado y se describen escenas de una realidad en la que interactuaban los alumnos con los vecinos.

En el tercer capítulo refiere la secuencia que se requirió para lograr la instrumentación de un sistema educativo nacional: en primera instancia, describe la transformación física de los edificios escolares; posteriormente, aparece la higiene escolar, que se sustentaba en el control de la salud a través de la alimentación y la higiene de los niños asistentes a las escuelas. Con estas acciones el gobierno federal tuvo un impacto más allá de la esfera pública y se adentró en el espacio privado, en la vivienda. Al mismo tiempo que regulaba la limpieza e higiene 
escolar, llevaba un control y uniformidad de los cuerpos infantiles y del colectivo familiar. Esto permite visualizar la participación de nuevos actores en la vida escolar, como los médicos y enfermeras, que se concentraban en el servicio de higiene escolar y cuya tarea consistía en la clasificación de la población infantil, para su debida atención médica.

La autora no sólo describe los logros y avatares de la educación primaria en la Ciudad de México durante las postrimerías del Porfiriato, sino que se adentra justo en esos años en que las fuerzas bélicas se apoderan de la ciudad, dando cuenta del cambio en el paisaje citadino. Después de que se pretendió imponer un modelo de ciudad y un modelo de escuela, llegó la revuelta; los motines urbanos no se hicieron esperar y las escuelas se mantuvieron en medio de trifulcas, de rupturas y revueltas.

En este cuarto capítulo, describe el tránsito que tuvieron las escuelas, al pasar de nacionales a ser de nuevo municipales, como lo dictaminó Venustiano Carranza durante los meses que duró su gestión. La inestabilidad política se vio reflejada en las penurias que tuvieron que pasar los maestros y padres de familia, para dar continuidad a la tarea colectiva de educar. Chaoul describe el abandono de las escuelas de la Ciudad de México durante 1913 y 1914, años en los que estuvo ocupada por las distintas fuerzas militares que pretendían tomar el poder. La autora recrea varias escenas escolares en las que nos lleva a mirar los efectos de la guerra, por ejemplo, para 1918 aún no se emitían lineamientos con respecto a los contenidos educativos, pero sí se imponía la intervención de la militarización en las escuelas. Con esto, los alumnos y maestros eran obligados a recibir instrucciones de soldados convertidos en instructores militares, quienes tenían la tarea de formar cuerpos de infantería en los centros de enseñanza. Relata, también, la resistencia de los maestros ante las leyes impuestas a nivel local, municipal o federal, así como los esfuerzos que realizaron para organizarse en lo que se denominó la Liga de profesores de la Ciudad de México, para la defensa de sus intereses.

Un libro que, sin duda, nos ofrece una retrospectiva para mirar en la frontera de los siglos XIX y Xx la interacción de diversos actores sociales en el ámbito educativo: médicos e inspectores escolares, arrendadores de casas, autoridades educativas y militares, entre otros; al mismo tiempo que no pierde de vista el protagonismo de los niños, maestros y padres de familia en sus tareas cotidianas escolares, ya fuera en tiempos de fiesta y lucimiento escolar o en tiempos aciagos y de revueltas sociales.

Este trabajo se une al conjunto de esfuerzos que la producción historiográfica de los últimos años nos ha dado. Constituye una aportación de la historiografía cultural que ofrece otras posibilidades para repensar la educación, desde una perspectiva distinta de un fenómeno histórico, dando luces a sucesos simultáneos que permiten tener una mejor comprensión del acontecimiento. Chaoul insiste en que no es suficiente con describir la promulgación 
o erogación de leyes educativas, sino hay que hurgar en busca de su impacto en la práctica y observar los beneficios o daños ocasionados a los protagonistas sociales.

Para concluir, me pregunto en torno a los posibles lectores de este libro. Me atrevo a sugerir que es una obra en la que pueden abrevar las nuevas generaciones de jóvenes, que se forman en las aulas con miras a ejercer la profesión magisterial, ya que ofrece múltiples pistas para entender los procesos históricos en los que fueron partícipes los maestros durante la gestación del sistema educativo mexicano. Al mismo tiempo, es un faro para aquellos maestros, historiadores o investigadores de la educación quienes emprenden travesías por el tiempo histórico, en busca de posibles horizontes desde donde atisbar y defender la esperanza educativa en México. 